\title{
A Comprehensive Literature Review of Thermochemical Conversion of Biomass for Syngas Production and Associated Challenges
}

\author{
GHULAMULLAH MAITLO*, RASOOL BUX MAHAR**, ZULFIQAR ALI BHATTI***, AND \\ IMRAN NAZIR UNAR***
}

RECEIVED ON 05.07.2018 ACCEPTED ON 17.08.2018

\begin{abstract}
The interest in the thermochemical conversion of biomass for producer gas production since last decade has increased because of the growing attention to the application of sustainable energy resources. Application of biomass resources is a valid alternative to fossil fuels as it is a renewable energy source. The valuable gaseous product obtained through thermochemical conversion of organic material is syngas, whereas the solid product obtained is char. This review deals with the state of the art of biomass gasification technologies and the quality of syngas gathered through the application of different gasifiers along with the effect of different operating parameters on the quality of producer gas. Main steps in gasification process including drying, oxidation, pyrolysis and reduction effects on syngas production and quality are presented in this review. An overview of various types of gasifiers used in lignocellulosic biomass gasification processes, fixed bed and fluidized bed and entrained flow gasifiers are discussed. The effects of various process parameters such as particle size, steam and biomass ratio, equivalence ratio, effects of temperature, pressure and gasifying agents are discussed. Depending on the priorities of several researchers, the optimum value of different anticipated productivities in the gasification process comprising better quality syngas production improved lower heating value, higher syngas production, improved cold gas efficiency, carbon conversion efficiency, production of char and tar have been reviewed.
\end{abstract}

Key Words: Biomass, Thermochemical, Gasification, Types of Gasifiers, Operating Parameters.

\section{INTRODUCTION}

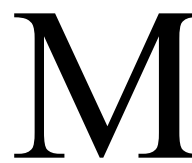

ounting trepidations about the ecological problems related to the fossil fuels usage, world energy strategy aims to the promotion and development of alternative energy resources for sustainable application along with less or no environmental problems [1]. Various initiatives have been taken and multiple targets are set to meet stringent emission requirements like roadmap 2050 [2], the framework for climate change 2030 [3], particularly 2020-20 targets as promoting up to $20 \%$ share of

Authors E-Mail: (metlo2696@yahoo.com, rb.mahar@faculty.muet.edu.pk, zulfiqar.bhatti@faculty.muet.edu.pk, imran.nazir@faculty.muet.edu.pk) * Department of Chemical Engineering, Dawood University of Engineering \& Technology, Karachi, Pakistan.

** US-Pakistan Centre for Advanced Studies in Water, Mehran University of Engineering \& Technology, Jamshoro, Pakistan

*** Department of Chemical Engineering, Mehran University of Engineering \& Technology, Jamshoro, Pakistan.

This is an open access article published by Mehran University Research Journal of Engineering and Technology, Jamshoro under the CC by 4.0 International License. 
renewable energy in EU (European Union) countries, by reducing $20 \%$ GHG (Greenhouse Gas) emissions into environment and $20 \%$ rise in energy efficiency in 2020 [4]. Alternative energy resources include wind, solar, tidal geothermal and biomass etc. are renewable and environmental friendly as compared to the fossil fuels. Among numerous alternative energy sources, the application of biomass as an alternative resource bring about many social, economic and environmental improvements. The management of biomass inappropriate manner reduces net carbon dioxide emissions almost zero and offers economic wellbeing of rural and semi-urban areas [1]. Biomass resources are extensive and copiously available in the world. However, one-third of total energy is obtained from biomass in developing countries of Asia and Africa. As the thermochemical transformation of lignocellulosic biomass is attractive prospect meant for the recovery of gas, liquid and solid products. The gas produced through thermochemical conversion of biomass is called synthesis gas or syngas. The syngas produced by thermochemical conversion of biomass possesses a substantial quantity of energy. The syngas obtained may further be exploited for power production and biofuel synthesis. Char produced during the gasification of biomass is organic inert material mainly containing carbon and ash. This transformation shows a partial oxidation of the carbon available in untreated biomass, usually takes place in the presence of gasifying carriers such as steam, carbon dioxide, air or oxygen. The condensation of heavier hydrocarbons takes place in temperature ranging from $250-300^{\circ} \mathrm{C}$. Various types of unwanted gases are also produced, $\mathrm{H}_{2} \mathrm{~S}$ (Hydrogen Sulfide), hydrochloric acid and inert gas $\mathrm{N}_{2}$ (Nitrogen). The presence of undesirable gases heavily relies on the treatment of raw materials and operational parameters of gasification unit. The composition of the syngas depends on the operating conditions, especially the amount of hydrocarbons and tar. Normally the LHV (Lower Heating Value) of syngas is observed from 4$13 \mathrm{MJ} / \mathrm{Nm}^{3}$ [5]. The amount of char produced strongly rests on gasification method and operational parameters. The lower heating value of char is in between $25-30 \mathrm{MJ} /$ $\mathrm{kg}$ [6]. The heat required to carry on the reaction is generally provided at the oxidation stage through allothermal or auto-thermal method. In the auto-thermal method of gasification, takes place through the internal heating of gasifier with partial combustion and in allothermal gasification process energy necessary to carry on the reaction is supplied externally. Thus the syngas produced has wide application for the synthesis of various chemicals including methanol, MTBE (Methyl Turt Butyl Ether) and DME (Dimethyl Ether). Syngas can be converted into liquid transportation fuel through Fischer-Tropsch synthesis methods depending on different $\mathrm{H}_{2} / \mathrm{CO}$ ratios [7]. Further, in Integrated Gasification Combined Cycle both heat and power could be achieved. However, fossil fuels consumption produces a large amount of greenhouse gases [8], it is important to reduce the environmental impact caused by the non-renewable sources. As from numerous renewable energy means biomass is utmost significant environmental friendly resource widely available around the world for the generation of syngas and electricity [9]. Moreover, raw biomass when compared with coal has low utilization efficiency because raw biomass possesses ahigh quantity of moisture, high hydrogen to carbon ratio as well as high oxygen to carbon ratio. The main stages in gasification are, drying (endothermic stage, heat is absorbed), oxidation (an exothermic stage, heat is evolved), pyrolysis, and reduction both are endothermic stages in gasification. The additional steps

Mehran University Research Journal of Engineering \& Technology, Volume 38, No. 2, April, 2019 [p-ISSN: 0254-7821, e-ISSN: 2413-7219] 
may be tar decomposition, in order to consider the creation of light hydrocarbons because of the disintegration of larger tar molecules [10]. Main steps in gasification processes are shown in Fig. 1 and are discussed in subsequent sections below. However, the overall energy structure consumes enormous quantities of natural resources and the most of the energy produced is derived from fossil fuels, which possesses serious environmental and health hazards. The more production of greenhouse gases results in severe global warming, which damages the ozone layer. Due to the high demand of energy, the number of fossil fuel power plants are installed that results in more production of carbon dioxide during fuel combustion, which is increased from $0-22 \times 10^{12} \mathrm{~kg}$ / year in between 1890-2009. Considering fossil fuels limitations, and the environmental glitches related to their application in the world is so far from attaining a sustainable energy future. Instead, we are strongly dependent on the nonrenewable energy sources [11].

The conversion of biomass into energy through different conversion routes is shown in Fig. 2. In this study, thermochemical conversion technologies for biomass into syngas its technical challenges, operating parameters and their effect on the syngas quality are reviewed.

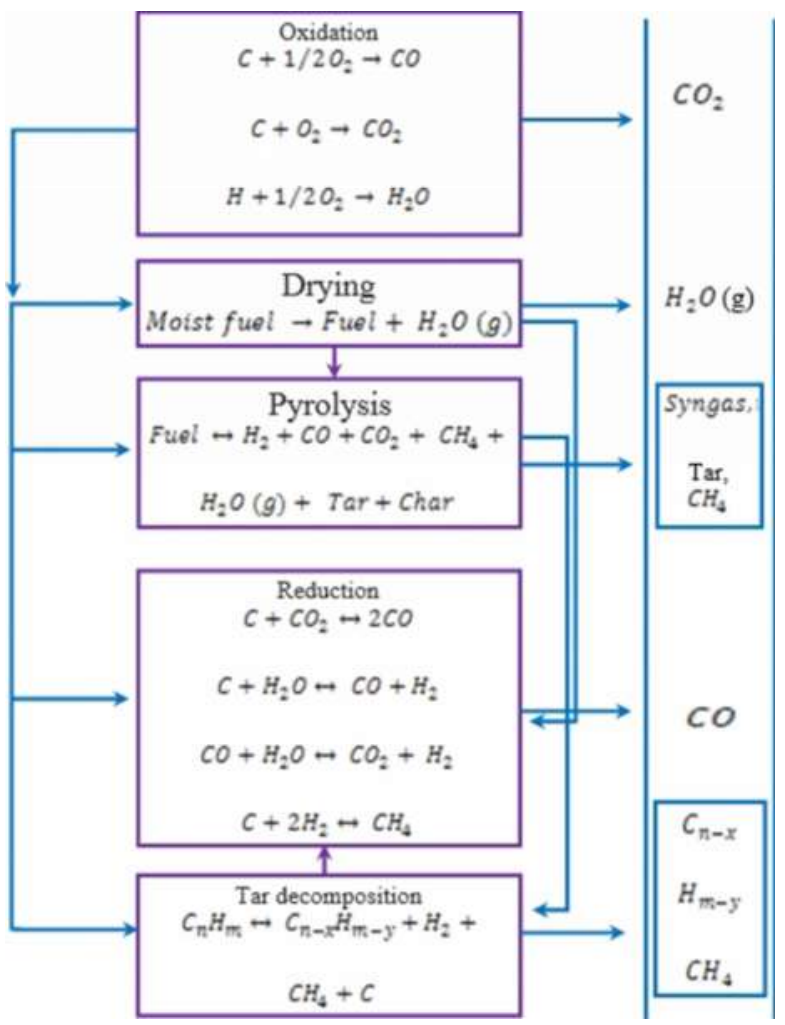

FIG. 1. MAIN STAGES IN GASIFICATION PROCESS [10]

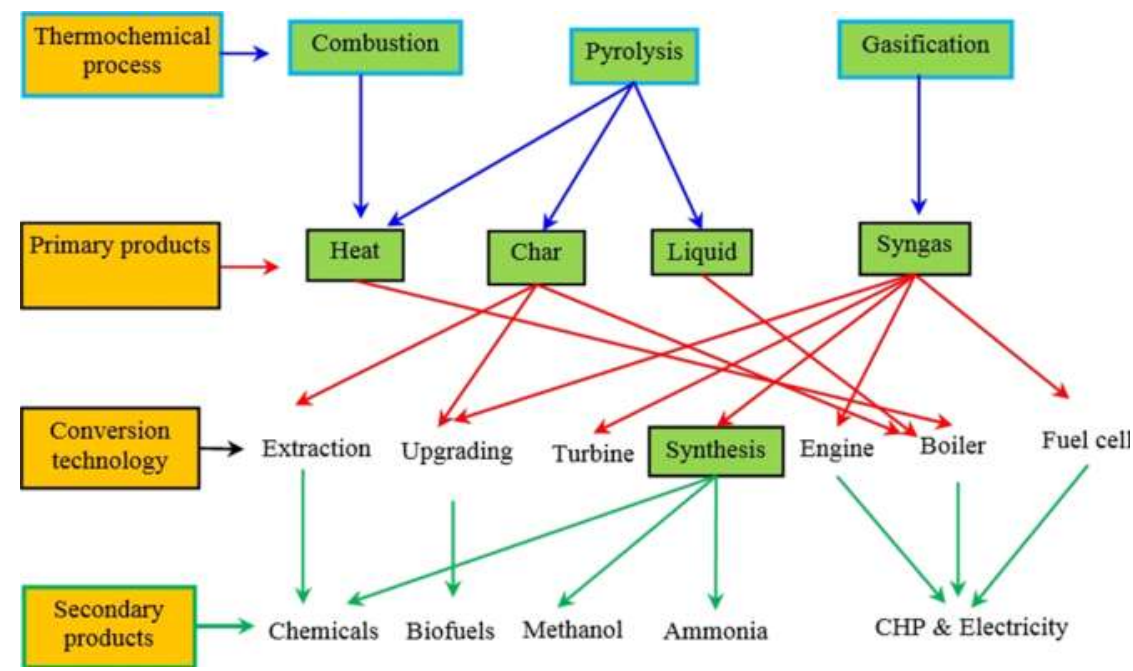

FIG. 2. THERMOCHEMICAL CONVERSION ROUTES FOR ENERGY PRODUCTION MAIN STEPS DURING GASIFICATION

Mehran University Research Journal of Engineering \& Technology, Volume 38, No. 2, April, 2019 [p-ISSN: 0254-7821, e-ISSN: 2413-7219] 


\subsection{Oxidation}

In gasification process, the oxidation of biomass is performed to attain and sustain the thermal energy required to carry out endothermic processes at the desired level. In oxidation stage, restricted supply of oxygen is maintained in order to attain the stoichiometric ratio to oxidize the only portion of the material. Regardless of fractional oxidation involve entire carbonaceous types including tars; it is probably to make sure that only chars and hydrogen present in syngas take part in the partial oxidation process. During oxidation processes the main reactions take place are listed as follow:

$$
\begin{aligned}
& \text { Char Combustin } \mathrm{C}+\mathrm{O}_{2} \rightarrow \mathrm{CO}_{2} \Delta \mathrm{H}=-394 \frac{\mathrm{KJ}}{\mathrm{mol}} \\
& \text { Hydrogen Combustin } \mathrm{H}_{2}+1 / 2 \mathrm{O}_{2} \rightarrow \mathrm{H}_{2} \mathrm{O} \Delta \mathrm{H}=-244 \frac{\mathrm{KJ}}{\mathrm{mol}} \\
& \text { Partial Oxidation } \mathrm{C}+1 / 2 \mathrm{O}_{2} \rightarrow \mathrm{CO} \Delta \mathrm{H}=-111 \frac{\mathrm{KJ}}{\mathrm{mol}}
\end{aligned}
$$

The thermal energy obtained in this step is required to maintain the whole process, whereas the combustion products are $\mathrm{CO}, \mathrm{CO}_{2}$ and water. When feedstock oxidation process is executed through the air the gas mixture may contain nitrogen, if only oxygen is used the nitrogen presence is practically absent in gas mixture.

\subsection{Moisture Content and Drying of Biomass}

The evaporation of moisture available in the feedstock is drying. The heat needed for the removal of moisture available in the feedstock is proportional to the moisture content within the biomass. In gasification generally, the heat needed for the removal of moisture is taken from the other stages of the gasification process. Drying is considered complete by increasing the temperature of biomass well above $150^{\circ} \mathrm{C}$ [12].

\section{$1.3 \quad$ Pyrolysis}

In this part of the gasification, thermochemical decomposition of feed takes place particularly, the breakdown of chemical bonds into smaller molecules having lower molecular weight are formed during pyrolysis phase. Pyrolysis products are mainly solids, liquids and gaseous fractions. The solid fractions obtained in this phase ranges from 5-10 weight percent for fluidized bed gasifier and 20-25 weight percent for fixed bed gasifier [13-14], is characterized by high heating value and high carbon content. The liquid fraction obtained in the form of tars fluctuates depending upon the type of gasifier used, the liquid tar content nearly $1 \%$ for downdraft gasifier, 1-5\% for bubbling fluidized bed gasifier and 10$20 \%$ for updraft gasifier. The tars are complex organic material, which may be condensed at lower temperature ranges. The gases obtained in pyrolysis phase vary 70 90 weight percent of the feed material. Gas produced at pyrolysis stage is called pyrolysis gas primarily consisting of $\mathrm{CO}, \mathrm{CO}_{2}, \mathrm{H}_{2}$ and light hydrocarbons, $\mathrm{CH}_{4}$ and insignificant parts of acid or inert gases that may not be condensed at ambient temperature. The temperatures are maintained from $250-700^{\circ} \mathrm{C}$ to carry out pyrolysis reactions. In pyrolysis reactions, heat is absorbed which is directed from oxidation stage of the gasification process. The overall pyrolysis reaction is given below [15].

$$
\text { Biomass } \underset{\mathrm{H}}{\stackrel{\mathrm{H}}{2}}+\mathrm{C}_{2}+\mathrm{CO}_{2}+\mathrm{CH}_{4}+\mathrm{H}_{2} \mathrm{O}(\mathrm{g}) \text { Tar }+ \text { Char }(\text { Endothermic })
$$

When biomass feedstock used for gasification contains cellulosic material nearly $50 \%$ of the weight, in such type of reactions the feed material is specified using the formula of cellulose $\mathrm{C}_{6} \mathrm{H}_{10} \mathrm{O}_{6}$. In pyrolysis reaction various complex processes are observed such as heat transfer, product diffusion from biomass pores towards gas phase reactions occurring in series, high temperatures are maintained for cellulosic materials at pyrolysis stage from $600-700^{\circ} \mathrm{C}$. 


\subsection{Reduction}

In reduction reactions, the product obtained react with homogenous and heterogeneous gasification reactions to form syngas. Reactions taking place at reduction stage are mainly.

Boundourad Reaction $\mathrm{C}+\mathrm{CO}_{2} \leftrightarrow 2 \mathrm{CO} \Delta \mathrm{H}=172 \frac{\mathrm{KJ}}{\mathrm{mol}}$

Reforming of Char $\mathrm{C}+\mathrm{CO}_{2} \leftrightarrow \mathrm{CO}+\mathrm{H}_{2} \Delta \mathrm{H}=131 \frac{\mathrm{KJ}}{\mathrm{mol}}$

Shift Reaction $\mathrm{CO}+\mathrm{H}_{2} \mathrm{O} \leftrightarrow \mathrm{CO}_{2}+\mathrm{H}_{2} \Delta \mathrm{H}=-41 \frac{\mathrm{KJ}}{\mathrm{mol}}$

Methanation Reaction $\mathrm{C}+2 \mathrm{H}_{2} \leftrightarrow \mathrm{CH}_{4} \Delta \mathrm{H}=-75 \frac{\mathrm{KJ}}{\mathrm{mol}}$

Both boudouard and char reforming reactions absorb heat and are well known as endothermic reactions during reduction stage [16], whereas, both water gas shift and methanation reactions are exothermic reactions. Reactions (4 and 7 are) chemical equilibrium reactions. According to thermodynamic equilibrium law in reactions 4 and 7 both product and reactants can coexist and maintain their concentration. The variations in temperature have a significant effect on the final gas composition. Lower temperature causes lower heating values of syngas and produces more tar, while higher temperatures upswing the oxidation of char and decrease the presence of tar in the syngas. The temperature effects are summarized in Fig. 3.

The effects of temperature on syngas production have guided to various technological solutions, producing syngas and a solid residue of different composition. The various temperatures at which gasification can be carried out at commercial level ranges from $800-1100^{\circ} \mathrm{C}$. When gasification is performed using oxygen the temperatures are maintained in the range of $500-1600^{\circ} \mathrm{C}$.

\section{TYPES OF GASIFIERS}

Gasifiers are generally of three types, as classified into fixed bed gasifiers, entrained flow gasifiers and fluidized bed gasifiers. Fixed bed gasifiers are further categorized as downdraft gasifiers, updraft gasifiers, cross draft gasifiers and open core gasifiers [17]. Whereas fluidized bed gasifiers are classified as bubbling fluidized bed gasifiers, circulating fluidized bed gasifiers and dual fluidized bed gasifiers [18-20]. Fixed bed gasifiers are less efficient and produce low heating value syngas, these gasifiers are appropriate for small and medium scale operations. Subsequently in fixed bed gasifiers mixing of feed does not take place, therefore to achieve a uniform temperature within the reactor is very difficult. As fluidized bed gasifiers have limited application when coal is used as a raw material for gasification due to low carbon conversion efficiency caused due to low bed temperature ranging from $800-1000^{\circ} \mathrm{C}$. Fluidized bed gasifiers are best suited for lignocellulosic materials as lignocellulosic materials gasifying at lower temperatures as compared to that of the coal. Problems associated with the operation of updraft and downdraft gasifiers are also obviated in fluidized bed gasifiers. Fluidized bed gasifiers have got impetus over fixed bed gasifiers, currently, the major focus is kept on fluidized bed gasifier development on a

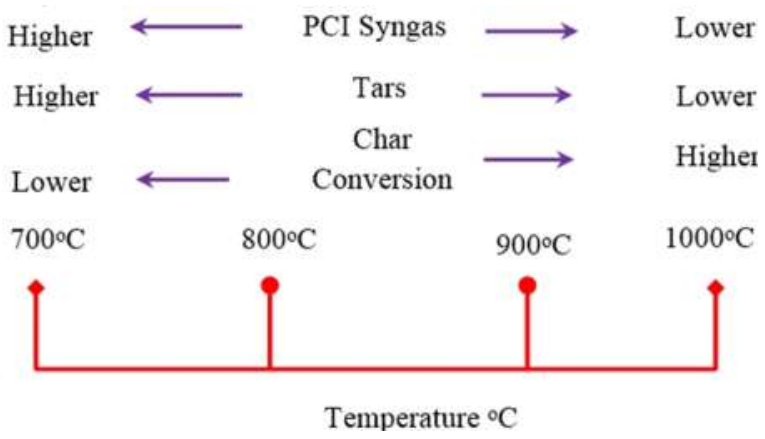

FIG. 3. TEMPERATURE VARIATIONS EFFECT ON SYNGAS CHARACTERISTICS

Mehran University Research Journal of Engineering \& Technology, Volume 38, No. 2, April, 2019 [p-ISSN: 0254-7821, e-ISSN: 2413-7219] 
commercial scale. A number of technologies have been explored regarding fluidized bed gasifiers involving in biomass gasification, among these technologies, two types are commonly employed for this purpose circulating fluidized beds and bubbling fluidized beds [21]. In this study fixed bed gasifiers, entrained flow gasifiers and fluidized bed gasifiers are discussed in subsequent sections (Fig. 4).

Depending on the nature and type of reaction air blown gasifier comprises on four segments including drying, pyrolysis, combustion and reduction segments.

\subsection{Updraft Gasifiers}

Updraft gasifier is the oldest and simplest gasifier used for biomass gasification. In updraft gasifier air and necessary gasifying agents are introduced from the bottom of the gasifier. The supplied air moves upward of the gasifier as represented in Fig. 5, whereas feed is introduced from the top of the updraft gasifier and moves downward under the force of gravity creating countercurrent flow within gasifier. The drying segment is positioned at the top of the gasifier where biomass is introduced followed by pyrolysis, reduction and oxidation segments. Biomass first moves into the drying section where moisture is removed by maintaining the temperature above $100^{\circ} \mathrm{C}$, during downward movement, biomass moves into pyrolysis section where biomass experiences

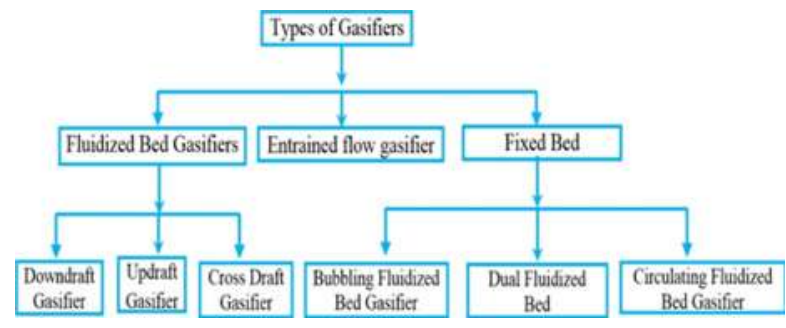

FIG. 4. TYPES OF GASIFIER USED IN BIOMASS GASIFICATION disintegration and is changed into gases and char, followed by reduction zone, where, volatile gases and char produced are further changed to carbon monoxide and hydrogen. Finally, the unconverted char settles down in combustion zone, where solid charcoal is further combusted resulting in heat, and heat is effectively transferred to the solid particles moving downward to maintain pyrolysis anddrying processes within the reactor.

In counter-currentgasification, syngas is collected from the low-temperature zone located at top of the reactor resulting in the substantial amount of tar production as presented in Table 1. Countercurrent gasifier can accept higher moisture containing biomass up to $60 \%$ [23]. The major problem associated with updraft gasifier is high tar content. If the gas produced is to be introduced to internal combustion engines for power generation, it must go through the series of filtration steps to cut the tar concentration to a satisfactory level. The tar removal process further adds a financial burden on the investors and reduces the efficiency of the whole process. A considerable research has been done on the updraft gasifier over the last few years.

$\downarrow$
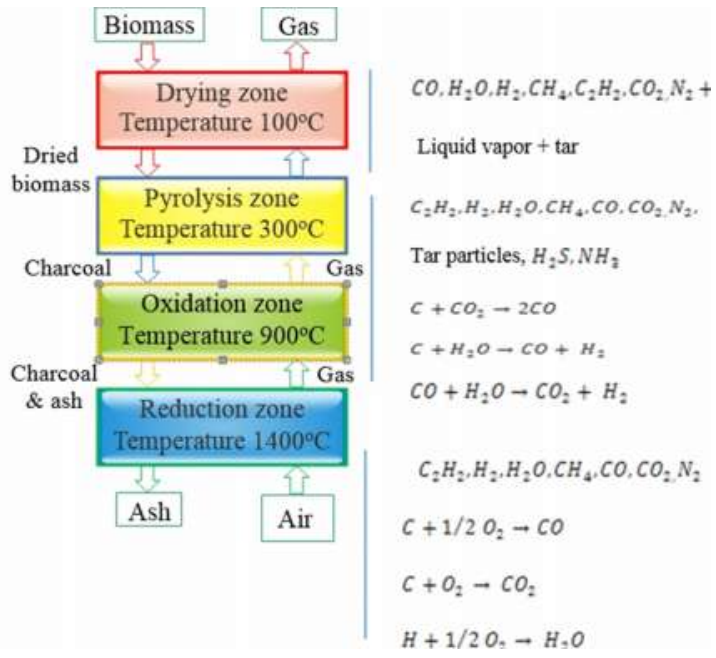

FIG. 5. THE ARRANGEMENT OF MULTIPLE STEPS IN UPDRAFT GASIFIER [22]

Mehran University Research Journal of Engineering \& Technology, Volume 38, No. 2, April, 2019 [p-ISSN: 0254-7821, e-ISSN: 2413-7219] 


\subsection{Downdraft Gasifier}

In downdraft gasifier, feedstock and air are introduced from the top of the gasifier in drying zone. The feed material and air move downward co-currently from drying, pyrolysis, oxidation and reduction segments of downdraft gasifier. Diverse reactions are carried out in all section of the gasifier and are shown in Fig. 6. The gas produced during gasification process is drawn out from the bottom of the gasifier. In comparison to the updraft, downdraft gasifier produces less tar in product gas because of its thermal cracking in pyrolysis and reduction zones. As product gas passes from high-temperature oxidation and reduction zones, nearly the entire organic load is converted to form syngas. Downdraft gasifiers produce better quality syngas when compared with updraft gasifiers.

It is important to maintain the temperature of oxidation zone greater than $1000^{\circ} \mathrm{C}$ and the equal spreading of biomass and the gasifying agent is essential for smooth operation. The clean gas gathered from the gasifier is most appropriate for gas engines and gas turbines, since the gas taken off from the downdraft gasifier possess relatively high temperature, needs cooling before downstream application [29]. The results obtained during the gasification of bagasse in downdraft gasifier reveal

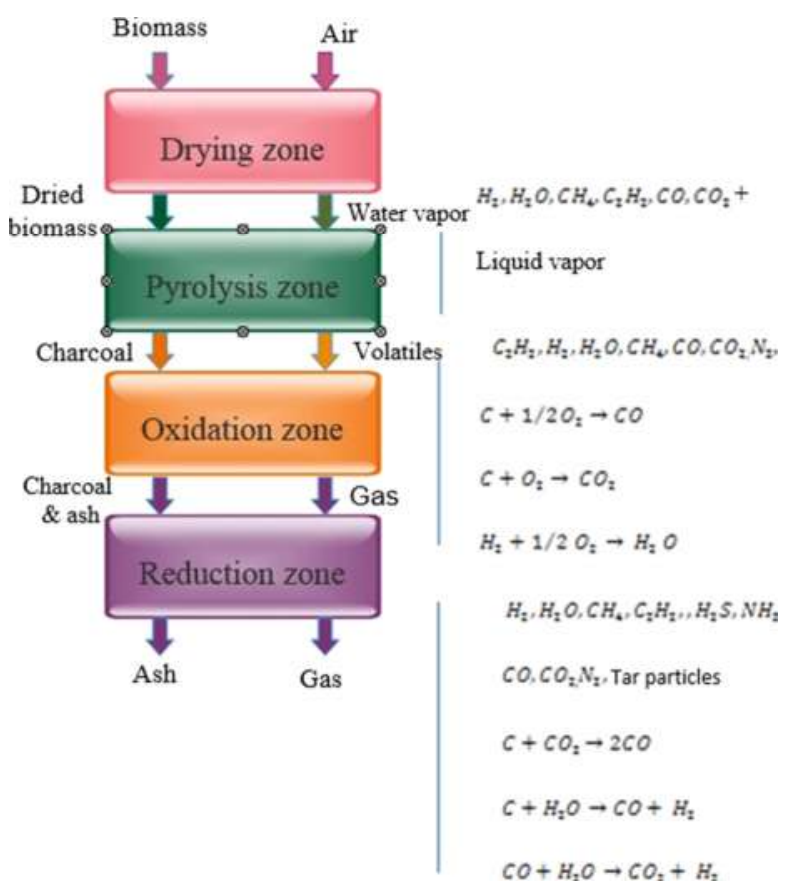

FIG. 6. THE ARRANGEMENT OF MULTIPLE STEPS IN DOWNDRAFT GASIFIER [22]

TABLE 1. GAS COMPOSITION IN PRODUCT GAS IN UPDRAFT GASIFIER UNDER DIFFERENT CONDITIONS

\begin{tabular}{|c|c|c|c|c|c|c|c|}
\hline Biomass Type & $\begin{array}{l}\text { Gasification } \\
\text { Temperature } \\
\left({ }^{\circ} \mathrm{C}\right)\end{array}$ & ER & $\begin{array}{l}\text { Gas Composition } \\
\text { (vol. \%) }\end{array}$ & $\begin{array}{c}\mathrm{LHV} \\
\left(\mathrm{MJN} / \mathrm{m}^{3}\right)\end{array}$ & $\begin{array}{c}\mathrm{HHV} \\
\left(\mathrm{MJ} \mathrm{N} / \mathrm{m}^{3}\right)\end{array}$ & $\begin{array}{r}\text { Power } \\
(\mathrm{KW})\end{array}$ & References \\
\hline Cedar Wood & $700-900$ & $0-0.30$ & - & $1-33.2$ & - & - & [24] \\
\hline Cedar Wood & $650-950$ & $0-0.30$ & $\begin{array}{l}\mathrm{H}_{2}(30-50), \mathrm{H}_{2} \mathrm{~S}(35-39 \mathrm{ppmv}) \\
\mathrm{CO}(22-53), \mathrm{CO}_{2}(25-30), \mathrm{CH}_{4}, \\
(8-10),), \mathrm{COS}(<2 \mathrm{ppmv}), \mathrm{N}_{2} \text { free }\end{array}$ & - & $2.4-3.5$ & 10 & {$[25]$} \\
\hline $\begin{array}{l}\text { Mesquite } \\
\text { Wood }\end{array}$ & & 2.7 & $\begin{array}{c}\mathrm{CO}(13-21), \mathrm{H}_{2}(1.6-3), \\
\mathrm{CO}_{2}(11-25), \mathrm{N}_{2}(60-64), \mathrm{CH}_{4}(0.40-6),\end{array}$ & - & $2.4-3.5$ & 10 & [26] \\
\hline Rice Straw & $700-850$ & $0.07-0.25$ & $\begin{array}{c}\mathrm{H}_{2}(6-10), \mathrm{CH}_{4}(4), \mathrm{CO}_{2}(11-25) \\
\mathrm{CO}(10-18), \mathrm{NH}_{3}(3100 \text { ppmv }) \\
\mathrm{Cl}_{2} \text { (ppmv) } \mathrm{N}_{2}(46-63),\end{array}$ & $0.47-1.92$ & $3.62-5.14$ & 45 & [27] \\
\hline Juniper Wood & - & 2.7 & $\begin{array}{c}\mathrm{H}_{2}(2.5-3.5), \mathrm{CH}_{4}(1.50-1.8), \mathrm{CO}(21-25), \\
\mathrm{CO}_{2}(14-19), \mathrm{N}_{2}(58-61)\end{array}$ & - & $3.5-3.9$ & 10 & [26] \\
\hline $\begin{array}{l}\text { Wood chip } \\
\text { Coconut Shell }\end{array}$ & $700-900$ & 0.3 & $\begin{array}{c}\mathrm{H}_{2}(22-27), \mathrm{CO}(27-40), \mathrm{CO}_{2}(39-42), \\
\mathrm{CH}_{4}(7-9),\end{array}$ & - & 17 & 15 & [19] \\
\hline $\begin{array}{l}\text { Agro land } \\
\text { Willow }\end{array}$ & $800-820$ & $0.35-0.39$ & $\begin{array}{c}\mathrm{H}_{2}(30-45), \mathrm{CH}_{4}(8-12), \mathrm{CO}(20-25) \\
\mathrm{CO}_{2}(15-20), \mathrm{COS}(200 \mathrm{ppmv}) \\
\mathrm{H}_{2} \mathrm{~S}(2300 \mathrm{ppmv})\end{array}$ & $2-12$ & - & 60 & [28] \\
\hline
\end{tabular}

Mehran University Research Journal of Engineering \& Technology, Volume 38, No. 2, April, 2019 [p-ISSN: 0254-7821, e-ISSN: 2413-7219] 
that $\mathrm{CO}, \mathrm{H}_{2}, \mathrm{CO}_{2}, \mathrm{CH}_{4}$ were $23,13,11$, and $4 \%$ respectively with $\mathrm{HHV}$ of $5 \mathrm{MJ} \mathrm{N} / \mathrm{m}^{3}$, and during the gasification of hazelnut shells the carbon dioxide concentration was observed slightly low and the heat content of syngas enriched to $6.250 \mathrm{MJ} \mathrm{N} / \mathrm{m}^{3}$ [30]. With the application of two-stage downdraft gasifier heating value was observed at $6.50 \mathrm{MJ} \mathrm{N} / \mathrm{m}^{3}$ having tar content of $0.0450 \mathrm{gN} / \mathrm{m}^{3}$, whereas total combustible gases were more than $45 \%$ (Table 2) [31].

\subsection{Entrained Flow Gasifiers}

In EFG (Entrained Flow Gasifier) raw material and air supply passage in the same direction (co-currently), the reactions occur in a dense cloud fine particles ranging from $(0.1-1 \mathrm{~mm})$ at a very high temperature and pressure changing in range of 19.70 and 69.10 atmosphere and the temperature is maintained well above $1000^{\circ} \mathrm{C}$. Among the various types of gasifiers, entrained flow gasifier is a suitable choice for industrial scale operation. Entrained flow gasifier holds high efficiency for the production of syngas. The fabrication material required for entrained flow gasifier is of high quality because very high temperature and pressure are maintained within the gasifier. Feedstock required for gasification in entrained flow gasifier is of fine quality powder in order to achieve maximum conversion efficiency. Furthermore, the high temperature and pressure cause low tar formation during conversion process [33]. EFG offer constant temperature, higher heating rate and short residence time, currently, these are employed mainly in coal and liquid fuels, thus have a little experience with biomass as a feedstock [34]. Several efforts have been carried out to maintain the required size of biomass to comply with gasifier requirements, but it adds to theeconomic burden of overall operational cost making it commercially unattractive option. Fuel particle size affects the entire successive steps such as fuel heating, reactantsand syngas quality. Pre-treatment of feedstock is necessary to lessen the bulk density and moisture level available in biomass for the healthier operation of the process. Nevertheless, steam gasification upturns the hydrogen content of product gas, thereby increasing the lower heating value [22]

(Fig. 7).

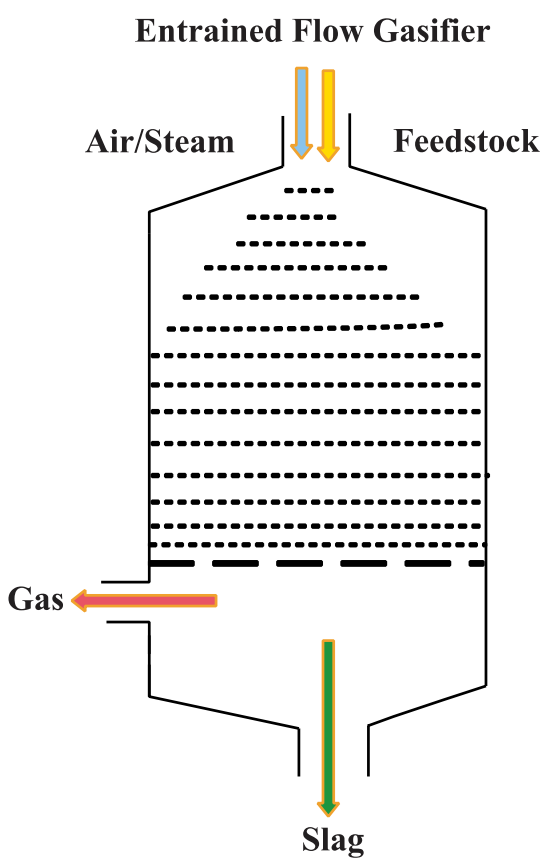

FIG. 7. THE ARRANGEMENT OF ENTRAINED FLOW GASIFIER.

TABLE 2. GAS COMPOSITION AND TAR CONTENT OF SYNGAS IN DOWN DRAFT GASIFIER

\begin{tabular}{|c|c|c|c|c|c|c|c|}
\hline Biomass Type & $\begin{array}{c}\text { Gasification } \\
\text { Temperature } \\
\left({ }^{\circ} \mathrm{C}\right)\end{array}$ & ER & $\begin{array}{c}\text { Gas Composition } \\
(\mathrm{vol} \%)\end{array}$ & $\begin{array}{c}\text { Tar } \\
\left(\mathrm{gN} / \mathrm{m}^{3}\right)\end{array}$ & $\begin{array}{c}\text { HHV/LHV } \\
\left(\mathrm{MJ} \mathrm{N} / \mathrm{m}^{3}\right)\end{array}$ & $\begin{array}{c}\text { Power } \\
(\mathrm{KW})\end{array}$ & $\begin{array}{c}\text { References } \\
\text { Bagasse }\end{array}$ \\
1040 & - & - & $0.367-.40$ & - & 50 & {$[29]$} \\
\hline Hazelnut Shells & 1000 & 0.351 & $\mathrm{H}_{2}(13), \mathrm{CO}(23), \mathrm{CO}_{2}(11), \mathrm{CH}_{4},(4)$ & - & 5.0 & 45 & {$[32]$} \\
\hline Wood Waste & $900-1050$ & $0.20-0.35$ & $\begin{array}{c}\mathrm{H}_{2}(8-12), \mathrm{CO}(15-22), \mathrm{CO}_{2}(5-8), \\
\mathrm{CH}_{4}(1-3), \mathrm{N}_{2}(60-70)\end{array}$ & - & $4.5-6.25$ & 15 & {$[30]$} \\
\hline
\end{tabular}

Mehran University Research Journal of Engineering \& Technology, Volume 38, No. 2, April, 2019 [p-ISSN: 0254-7821, e-ISSN: 2413-7219] 


\subsection{Bubbling Fluidized Bed Gasifiers}

These gasifiers are simplest and low-cost gasifiers, used for continuous biomass gasification. BFB (Bubbling Fluidized Bed) gasifiers can be operated at a varied range of feedstocks with different particle amounts comprising powdered biomass. High heat transfer rate between bed material and fuel is achievable in BFB gasifier, besides that uniform temperature throughout the bed area can be maintained within gasifier. BFBs are effective to deliver uniform syngas production during operation. The syngas produced contains a lesser quantity of unconverted carbon and tar $[35,36]$. BFB gasifiers are commonly used in biomass gasification operations, numerous investigations are reported in literature about the performance of BFBs nevertheless, the output varies in many inquiries regarding the desired quality of final product. It is difficult to attain the high solid conversion in BFB gasification due to the back mingling of particles. Even though higher mixing rates in BFBs enhances the product level. In BFBs mixing of partially and fully gasified constituents' effects on solid stream comprising partly gasified particles which decrease the conversion of solids within the gasifier. The oxygen diffusion rate is very slow in gasifier creating an oxidizing state in the reactor thus dropping the gasification efficiency. Above mentioned intrinsic restrictions of BFB gasification adversely affects the syngas production. These inherent limitations are overwhelmed in CFBs (Circulating Fluidized Beds) by providing extended solid residence time with the help of a solid circulating loop [37].

\subsection{Circulating Fluidized Bed Gasifiers}

In CFBs excessive rate of the fluid is maintained within the reactor in order to create a turbulent stream regime which entrains the bed particles and char in the gas stream. The entrained particles present in circulating streams are gathered from the top and moved to another unit for further operations. However, in external CFB gasifiers, the solid particles are gathered into a cyclone, parted from the gas phase and recycled to the gasifier. The separation of particles continues throughout the operation period of the gasifier to enhance the residence time of solids [35]. The main problem associated with external (CBFs) is the addition of solid separation unit and the equipment required for the transportation of gathered solids recycled to the gasifier. The addition of solid separation equipment and solid return equipment further increase the installation cost along with causing difficulties in controlling of the process [38]. In recent years internal CFB gasifiers are considered as an attractive choice for gasification. Two separate chambers are provided in internal CFB gasifiers, these chambers function as a FBF bed gasifier and other chamber function as a pneumatic riser combustor. Bed material circulates between two chambers enabling the separation of tar and other residues which are further moved to the combustion chamber. Air is provided to carry out the char combustion, heat produced during the combustion of char is directed to combustion chamber which increases the temperature of particles available in the combustion chamber. The hot particles provide the heat necessary for endothermic steam gasification. They are sometimes termed as dual fluidized bed gasifiers as they comprise of BFB gasifier and CFB combustor, several studies are executed regarding CFBs and copious research originates in literature showing simulation and modelling of CFBs which may assist in the optimization of process parameters, design andscale-up of the gasifier. In CFB prolonged catalytic activity is achievable when compared with BFBs, whereas due to fouling in BFBs prolonged catalytic activity is difficult to maintain owing to deposition of carbon on a catalytic surface. The fouling of surface can be avoided in CFBs because of the burning of deposited carbon in the circulation process [39]. The operating parameters CFB gasifiers and their impact on syngas quality are discussed in subsequent sections.

Mehran University Research Journal of Engineering \& Technology, Volume 38, No. 2, April, 2019 [p-ISSN: 0254-7821, e-ISSN: 2413-7219] 


\section{MAIN FACTORS IN FLUIDIZED BEDS}

For proper working of a biomass gasifier and the effect of different operating parameters on gasification performance requires a complete understanding of the process parameters. Lignocellulosic biomass possesses different properties such as morphological chemical and physical properties that may upset the overall process parameters, if not taken into consideration before the design and operation of the gasifier [40]. The selection of biomass for gasification significantly depends on its heating value. Biomass materials possessing greater heat content improve the economy and performance of the plant. As fluidized beds provide effective heat transfer rates and can be operated at varying varieties of feedstocks [41]. The results of proximate and ultimate analysis of several feedstocks are shown in Table 3. For better syngas quality and minimizing the char and tar content in outlet streams, numerous researchers have been performed on different feedstocks in order to understand the kinetic characteristics before its gasification to happen.

TABLE 3. THE ULTIMATE AND PROXIMATE ANALYSIS OF BIOMASS.

\begin{tabular}{|c|c|c|c|c|c|c|c|c|c|c|c|}
\hline \multirow{2}{*}{ Biomass Type } & \multicolumn{5}{|c|}{ Ultimate Analysis (Dry Basis, wt. \%) } & \multicolumn{4}{|c|}{ Proximate Analysis $(\% \mathrm{w} / \mathrm{w})$} & \multirow{2}{*}{$\begin{array}{c}\mathrm{LHV} \\
(\mathrm{MJ} / \mathrm{kg})\end{array}$} & \multirow{2}{*}{ References } \\
\hline & $\mathrm{C}$ & $\mathrm{H}$ & $\mathrm{N}$ & $\mathrm{O}$ & $\mathrm{S}$ & $\mathrm{FC}$ & M & $\mathrm{VM}$ & Ash & & \\
\hline Cedar wood & 51.10 & 5.90 & 0.12 & 42.50 & 0.020 & $18-20$ & a & $80-82$ & 0.3 & 19.26 & {$[42]$} \\
\hline Olive oil residue & 50.70 & 5.89 & 1.36 & 36.97 & 0.30 & 19.4 & 9.5 & 76 & 4.6 & 21.2 & {$[43]$} \\
\hline Wood sawdust & 46.20 & 5.1 & 1.5 & 35.4 & 0.06 & 17.9 & 10.4 & 70.4 & 1.3 & 18.81 & {$[44]$} \\
\hline Rice straw & 38.61 & 4.28 & 1.08 & 37.16 & 0.65 & 16.55 & 5.58 & 65.23 & 12.64 & 14.40 & {$[45]$} \\
\hline Risk husk & 45.8 & 6.0 & 0.3 & 47.9 & - & 13.1 & 12.3 & 73.8 & 0.8 & 13.36 & {$[46]$} \\
\hline Spruce wood pellet & 49.3 & 5.9 & 0.10 & 44.4 & - & 17.10 & 8.4 & 74.2 & 0.30 & 18.5 & {$[47]$} \\
\hline Pine sawdust & 50.54 & 7.08 & 0.15 & 41.11 & 0.57 & 17.16 & $\mathrm{a}$ & 82.29 & 0.55 & 20.54 & {$[14]$} \\
\hline Coffee ground & 52.97 & 6.51 & 2.8 & 36.62 & 0.05 & 16.7 & 10.5 & 71.8 & 1.00 & 22 & {$[48]$} \\
\hline Coffee husk & 46.8 & 4.9 & 0.6 & 47.1 & 0.6 & 14.30 & 10.4 & 74.3 & 1.00 & 16.54 & {$[46]$} \\
\hline Grapevine pruning waste & 46.97 & 5.8 & 0.67 & 44.49 & 0.01 & 19.78 & $\mathrm{a}$ & 78.16 & 2.06 & 17.91 & [49] \\
\hline Larch wood & 44.18 & 6.38 & 0.12 & 49.32 & & 14.86 & 8.16 & 76.86 & 0.12 & 19.45 & {$[50]$} \\
\hline Sugarcane Bagasse & 48.58 & 5.79 & 0.2 & 38.94 & 0.050 & $28.7-30.7$ & a & $67-70$ & 1.26 & 19.05 & {$[51]$} \\
\hline Jute stick & 49.79 & 6.02 & 0.19 & 41.37 & 0.050 & 21.4-23.4 & $\mathrm{a}$ & $76-78$ & 0.62 & 19.66 & {$[51]$} \\
\hline Peach stone & 51.95 & 5.76 & 0.79 & 40.7 & 0.01 & 18.10 & 8.53 & 81.3 & 0.65 & 21.6 & {$[52]$} \\
\hline Corn cob & 40.22 & 4.11 & 0.39 & 42.56 & 0.04 & 16.11 & 9.71 & 71.21 & 2.97 & 16.65 & {$[53]$} \\
\hline Cotton stem & 42.8 & 5.3 & 1.00 & 38.5 & 0.20 & 15.50 & 7.9 & 72.3 & 4.30 & 15.2 & [54] \\
\hline Wheat straw & 46.10 & 5.6 & 0.5 & 41.7 & 0.08 & 18.1 & $\mathrm{a}$ & 75.8 & 6.10 & 17.2 & {$[55]$} \\
\hline Camphor wood & 43.43 & 4.84 & 0.32 & 38.53 & 0.100 & 14.750 & 12.29 & 72.47 & 0.49 & 17.48 & {$[56]$} \\
\hline straw & 36.57 & 4.91 & 0.57 & 40.70 & 0.14 & 17.910 & 8.5 & 64.98 & 8.61 & 14.6 & [39] \\
\hline Switch grass & 47 & 5.3 & 0.5 & 41.4 & 0.10 & 17.10 & 20 & 58.4 & 4.6 & 18.7 & [57] \\
\hline Beech wood & 48.27 & 6.36 & 0.14 & 45.2 & - & 18 & $\mathrm{a}$ & 81 & 0.8 & 19.2 & {$[58]$} \\
\hline
\end{tabular}




\subsection{Effect of Temperature}

Bed temperature during the operational process of the gasifier effects on the heating value and composition of the syngas produced. Based on Le Chatelier's principle, the variations in temperature effects on syngas composition rest on thermodynamic characteristics of the reaction. In endothermic reactions high-temperature increase syngas production, while in exothermic reactions high temperature favors reactants. The purpose of gasification is to produce a syngas enriched in $\mathrm{CH}_{4}, \mathrm{CO}$ and $\mathrm{H}_{2}$ having medium to a high heating value that is appropriate for turbines and internal combustion engines [59]. Increase in temperature increases combustion rate producing additional amounts of $\mathrm{CO}_{2}$ and $\mathrm{H}_{2} \mathrm{O}$ production. It has been investigated that high temperature enhances carbon conversion efficiency, produce less tar and char quantities. Rice husk gasification was observed at 700$800^{\circ} \mathrm{C}$, it was monitored that rise in temperature from 700 $800^{\circ} \mathrm{C}$, the concentration of $\mathrm{H}_{2}$ (Hydrogen) increased from $5.370-7.460 \%$. Aresearch was done by varying temperature in the range of $650-850^{\circ} \mathrm{C}$. The maximum carbon conversion efficiency was achieved $82 \%$ and energy efficiency of $96 \%$ at $850^{\circ} \mathrm{C}$ while increasing temperature from $650-850^{\circ} \mathrm{C}$ improved hydrogen content from 4-15\% [60].

\subsection{Effects of Gasifying Agent}

Numerous researches have been done on biomass gasification through FBG (Fluidized Bed Gasifiers) using different gasifying agents such as oxygen, steam and air, as gasifying agents [61]. Biomass gasification systems using air as a gasifying agent have been used on an industrial scale in various countries, air as a gasifying agent upsurges the overall feasibility of the gasification unit. Nonetheless, the addition of air as a gasifying agent produces syngas highly diluted by nitrogen available in the air with having Lower Heating Value in the range of 4.0-6.0 MJ $/ \mathrm{m}^{3}$ and $\mathrm{H}_{2}$ content in the range of $8-14$ volume $\%$, which is effective for electricity generation [61-62]. When biomass gasification is performed using $\mathrm{O}_{2}$ enriched air gasification systems produces syngas having medium heating value, this system involves oxygen production equipment, which results ina rise in installation and operational cost of the process. Whereassteam-based gasification units produce syngas having heating value in the range of $10-16 \mathrm{MJ} / \mathrm{m}^{3}$ and $\mathrm{H}_{2}$ in range of $30-60$ volume $\%$ while endothermic reactions reduce the temperature of the bed, supplementary equipment is necessary to maintain the temperature of the bed above $700^{\circ} \mathrm{C}[63]$. In gasification systems using steam- oxygen as a gasifying agent, the heat required is directed from partial oxidation reactions. The syngas formed in steamoxygen gasification has a high $\mathrm{H}_{2}$ content and dilution with nitrogen is not favorable whereas, the cost incurred on pure $\mathrm{O}_{2}$ is high making the overall process unfavorable on an industrial scale. For distinct feedstock flow rate, two ratios are necessary to be controlled for the evaluation of the gasification plant. One is Equivalence ratio when air or oxygen gasification is used while for steam to biomass ratio when steam is used as a gasifying agent.

\subsection{Effect of Equivalence Ratio}

In biomass gasification one of the most important parameters taken into consideration throughout the operation of the plant is ER (Equivalence Ratio). It is the amount of air to biomass weight ratio divided by stoichiometric air to biomass weight ratio required for complete burning of biomass [64]. It is noticed that maximum combustion happens at high ER when the higher quantity of air is supplied into the reactor, it increased char combustion to generate $\mathrm{CO}_{2}$, reducing the amount of combustible gases production such as $\mathrm{H}_{2}, \mathrm{CH}_{4} \mathrm{CO}$. Besides that increase in ER results decrease in the LHV of syngas as more ER encumbers the production of $\mathrm{CH}_{4}$ and light hydrocarbons possessing fairly greater heating

Mehran University Research Journal of Engineering \& Technology, Volume 38, No. 2, April, 2019 [p-ISSN: 0254-7821, e-ISSN: 2413-7219] 
values. At high ER ratio nitrogen available in air further, dilute the syngas reducing its energy content. Various studies carried out on ER have revealed that too small ER is also disparaging and adversely affect the gasification process as it causes the decrease in reactor temperature [14]. Hence, the appropriate value for equivalence ratio is from 0.20-0.40. ER value changes depending upon the required operating parameters and subsequent application of syngas [65]. Combustion of raw syngas in the downstream heating system, tar is not considered as a thoughtful concern, only product gas may possess high heating value, in this case, gasifier used can be supplied at minimum ER of nearly 0.20 . When the temperature of the gasifier is maintained below $850^{\circ} \mathrm{C}$ tar yield increases, to control the tar formation ER should be increased to about 0.3-0.4 for better results [65]. Experimental results obtained by various researchers revealed that enhancing the ER above 0.4 decreased the quantity of $\mathrm{CO}, \mathrm{CH}_{4}, \mathrm{H}_{2}$ and $\mathrm{C}_{2} \mathrm{H}_{2}$. The maximum concentration of $10 \%$ was observed at ER 0.260, besides that experimental results revealed that increasing the ER tar concentration lessened and at ER of 0.450 tar concentration further reduced to $2.0 \mathrm{~g} / \mathrm{m}^{3}$. While LHV achieved was 5.20, and 3.50-4.50 MJ $/ \mathrm{m}^{3}$ at ER of $0.250-0.450$ respectively. It was observed from the gathered data that ER is in direct relationship with syngas yield.

\subsection{Effect of Steam and Biomass Ratio}

Steam and biomass ratio is the flow rate of steam divided by the biomass flow rate within the reactor for gasification of the biomass. Steam and biomass ratio in gasification is an important parameter taken into consideration during operation of gasifier. Lv et. al. [14] performed various experiments to investigate the significance of steam and biomass ratio on the quality of syngas by varying both ratios from 0.0-4.04, they found that addition of steam to the gasifier enhanced the lower heating value of gas, carbon conversion efficiencyand syngas production. According to their research steam to biomass ratio in the range of 1.35 4.040 is optimum at which, more steam reforming reactions of $\mathrm{CO}, \mathrm{CH}_{4}$ and $\mathrm{C}_{2} \mathrm{H}_{2}$ occurred due to the introduction of steam which produced more concentration of $\mathrm{H}_{2}$ and $\mathrm{CO}$ Qin et. al. [66] examined the outcome of steam and biomass ratio on the formation of tar and its properties by varying steam to biomass ratio in the range of $0.49-2.66$ at $900^{\circ} \mathrm{C}$, found that by increasing ratio, tar formation gradually decreased from $3.87-1.71 \%$. At high steam and biomass ratio aromaticity of tar further reduced. The effect of steam-oxygen gasification on product distribution was analyzed by various researchers and observed by varying steam to oxygen ratio and steam, oxygen to biomass ratios from 2.0-3.0 mole/mole and $0.60-1.60 \mathrm{~kg} / \mathrm{kg}$ correspondingly. The $\mathrm{H}_{2}$ content of the syngas was 14-30 volume percent the decrease in $\mathrm{H}_{2}$ was noticed as the steam to biomass ratio was improved or the steam to oxygen ratio was steadily lessened. However, when the quantity of $\mathrm{O}_{2}$ was increased more quantity of $\mathrm{H}_{2}$ was combusted in the gasifier, the alike tendency was found for $\mathrm{CO}$, by changing the ratios and its concentration in the syngas was from 30-50 volume percent. As the gasifying agent to biomass ratio increased to a value above 1 , it decreased the char yield to about $10 \%$.Using steam in gasification process produce more $\mathrm{H}_{2}$. Efforts are made to increase the production of syngas with a high concentration of $\mathrm{H}_{2}$ and at the meantime capturing of $\mathrm{CO}_{2}$ to increase the process performance. Limestone (CAO) is commonly used as a bed material to capture $\mathrm{CO}_{2}$ in steam gasification process [50].

\subsection{Effect of Biomass Size}

Biomass size significantly affects the gasification efficiency, the smaller particle size of biomass raises 
the overall efficiency of gasification unit, however, thesmaller size of biomass increases the operational amount of the unit. A plant having 5-10 MW generation capacity, nearly $10 \%$ of the amount of energy produced is necessary to reduce the size of biomass [67]. While larger particle size decreases the initial treatment rate of biomass and increases devolatilization time. It is necessary to maintain balance by examining the outcome of biomass particle size on the overall efficiency of the process. Ly et. al. [14] experimented about the influence of particle size on the quality of syngas in four different assortments of 0.2-0.3, 0.45$0.6,0.3-0.45$ and $0.5-0.9 \mathrm{~mm}$. They investigated and concluded that lesser size of particles produced more $\mathrm{C}_{2} \mathrm{H}_{4}, \mathrm{CO}, \mathrm{CH}_{4}$ and less quantity of $\mathrm{CO}_{2}$ in contrast to larger particle size. With the application of small biomass gasification particle size, syngas yield, LHV, and carbon conversion efficiency increased. Small biomass particle size offers more surface area and greater heat transfer rate. Smaller particle size served in the production of more light gases and less quantity of condensate and char. In terms of cost comparison gasification of coal and biomass through thermochemical conversion process is one of the most economical and simple technology among the various renewable energy technologies. The biomass-based and coal power generation plants can be in the $1-20 \mathrm{MW}$ capacity range or higher. The smaller size of the plant is supported, where the biomass resources are available. Through the installation of the smaller size of power plants in biomass zones will reduce the transportation cost of the raw material [68]. The capital cost of energy produced using biomass and coal is lower when compared with wind energy and considerably lower than the electricity generated using diesel as a fuel. Therefore, the best option among various energy conversion technologies is thermochemical conversion of feedstock for energy production.

\subsection{Effect of Catalyst}

In biomass and coal gasification different types of catalysts are used in order to enhance the syngas composition in terms of $\mathrm{CH}_{4}, \mathrm{CO}$ and $\mathrm{H}_{2}$ production. The most common catalysts normally used include $\mathrm{MgO}$, $\mathrm{Al}_{2} \mathrm{O}_{3}, \mathrm{SiO}_{2}, \mathrm{TiO}_{2}, \mathrm{Fe} / \mathrm{CaO}$ catalysts. However, the order of catalytic activity in Methanation reaction was $\mathrm{MgO}$, $\mathrm{Al}_{2} \mathrm{O}_{3}, \mathrm{SiO}_{2}, \mathrm{TiO}_{2}[69]$. The addition of $\mathrm{Ni}-\mathrm{W} / \mathrm{TiO}_{2}-\mathrm{SiO}_{2}$ catalyst during gasification produces hydrogen enriched syngas. At higher temperatures syngas production increases because of the acceleration of reaction rate resulting in maximum production of syngas 63 weight percent and $\mathrm{H}_{2}$ yield $172 \mathrm{ml} / \mathrm{g}$ biomass [5].

\section{CONCLUSION}

Several efforts are taken to reduce the fossil fuels consumption and finding alternative energy resources that could meet the energy demand at the global level. In recent times, significant consideration has been devoted to biomass gasification technologies. The global availability of biomass and its thermochemical conversion in a number of valuable products make it one of the better alternative energy resource having the potential to replace fossil fuels. However, several investigations have been carried out on thermo chemical conversion of lignocellulosic biomass into syngas via fixed bed, fluidized bed and EFG. Different operating parameters have been examined to enhance the efficiency of the overall process. The better efficiency of FBG has been confirmed in the literature by a number of scholars as well as numerous effective operations of commercial plants in developed countries. In literature, it has been investigated that high temperature enhances carbon conversion efficiency, produces less tar and char

Mehran University Research Journal of Engineering \& Technology, Volume 38, No. 2, April, 2019 [p-ISSN: 0254-7821, e-ISSN: 2413-7219] 
quantities. For rice husk gasification, the rise in temperature from $700-800^{\circ} \mathrm{C}$ the concentration of hydrogen $\left(\mathrm{H}_{2}\right)$ increased from 5.370-7.460\%. ER from 0.30.4 produces less quantities of tar and enhances the syngas production. Experimental results obtained by various researchers revealed that enhancing the ER above 0.4 decreased the quantity of $\mathrm{CO}, \mathrm{CH}_{4}, \mathrm{H}_{2}$ and $\mathrm{C}_{2} \mathrm{H}_{2}$. Besides that, smaller size of feedstock produces more $\mathrm{C}_{2} \mathrm{H}_{4}, \mathrm{CO}, \mathrm{CH}_{4}$ and less quantity of $\mathrm{CO}_{2}$ in contrast to larger particle size. Whereas using steam in gasification process as a gasifying agent produce more $\mathrm{H}_{2}$. Nevertheless, further exploration is necessary to increase the gas quality meant for its marketable uses with high energy content. For better syngas quality FBG with steam may increase the producer gas production and quality.

\section{ACKNOWLEDGMENT}

The authors are thankful to the Dawood University of Engineering \& Technology, Karachi, and Mehran University of Engineering \& Technology, Jamshoro, Pakistan, for providing valuable resources and support in the accomplishment of this review article.

\section{REFERENCES}

[1] Lapuerta M.N., Hernande J.J., and Rodrýiguez J.N., "Kinetics of Devolatilisation of Forestry Wastes from Thermogravimetric Analysis”, Biomass and Bioenergy, Volume 27, pp. 385-391, October, 2004.

[2] Foundation, E.C., "Roadmap 2050: APractical Guide to a Prosperous, Lowcarbon Europe", April, 2010.

[3] Commission, E.E., "A Policy Framework for Climate and Energy in the Period from 2020 to 2030", Technical Report European Commission, Volume 15, pp. 18, February, 2014.
[4] Commission, E.E., "Analysis of Options to Move Beyond 20\% Greenhouse Gas Emission Reductions and Assessing the Risk of Carbon Leakage", Commission Staff Working Document, SEC, Volume 650, 2010.

[5] Liu, B., and Ji, S., "Comparative Study of Fluidized-Bed and Fixed-Bed Reactor for Syngas Methanation Over $\mathrm{Ni}-\mathrm{W} / \mathrm{TiO}_{2}-\mathrm{SiO}_{2}$ Catalyst”, Journal of Energy Chemistry, Volume 22, pp. 740-746, January, 2013.

[6] Rauch, R., Hrbek, J., and Hofbauer, H., "Biomass Gasification for Synthesis Gas Production and Applications of the Syngas", Wiley Interdisciplinary Reviews: Energy and Environment, Volume 3, pp. 343-362, 2014.

[7] Woolcock, P.J., and Brown R.C., "A Review of Cleaning Technologies for Biomass-Derived Syngas", Biomass and Bioenergy, Volume 52, pp. 54-84, May, 2013.

[8] Emami T.L., Irfan, M.F., Wan Daud, W.M., and Chakrabarti, M., "The Effect of Temperature on Various Parameters in Coal, Biomass and CO-Gasification: A Review", Renewable and Sustainable Energy Reviews, Volume 16, pp. 5584-5596, October, 2012.

[9] Abdollahi, M., Yu, J., Hwang, H.T., Liu, P.K., Ciora, R., and Sahimi, M., "Process Intensification in Hydrogen Production from Biomass-Derived Syngas”, Industrial \& Engineering Chemistry Research, Volume 49, pp. 10986-10993, 2010.

[10] Molino, A., Chianese, S., and Musmarra, D., "Biomass Gasification Technology: The State of the Art Overview", Journal of Energy Chemistry, Volume 25, pp. 10-25, January, 2016.

[11] Masnadi, M.S., Grace, J.R., Bi, X.T., Lim, C.J., and Ellis, N., "From Fossil Fuels Towards Renewables: Inhibitory and Catalytic Effects on Carbon Thermochemical Conversion during Co-Gasification of Biomass with Fossil Fuels", Applied Energy, Volume 140, pp. 196-209, 2015.

[12] Hamelinck, C.N., Faaij, A.P., Uil, H., and Boerrigter, H., "Production of FT Transportation Fuels from Biomass; Technical Options, Process Analysis and Optimisation, and Development Potential", Energy, Volume 29, pp. 1743-1771, September, 2004. 
[13] Li, X.T., Grace, J.R., Lim, C.J., Watkinson, A.P., Chen, H.P., and Kim, J.R., "Biomass Gasification in a Circulating Fluidized Bed", Biomass and Bioenergy, Volume 26, pp. 171-193, February, 2004.

[14] Lv, P.M., Xiong, Z.H., Chang, J., Wu, C.Z., Chen, Y., and Zhu, J.X., "An Experimental Study on Biomass AirSteam Gasification in a Fluidized Bed", Bioresource Technology, Volume 95, pp. 95-101, October, 2004.

[15] Widyawati, M., Church, T.L., Florin, N.H., and Harris, A.T., "Hydrogen Synthesis from Biomass Pyrolysis with in Stu Carbon Dioxide Capture Using Calcium Oxide", International Journal of Hydrogen Energy, Volume 36, pp. 4800-4813, April, 2011.

[16] Zhang, J., Weng, X., Han, Y., Li, W., Gan, Z., and Gu, J., "Effect of Supercritical Water on the Stability and Activity of Alkaline Carbonate Catalysts in Coal Gasification", Journal of Energy Chemistry, Volume 22, pp. 459-467, May, 2013.

[17] McKendry, P., "Energy Production from Biomass (Part3): Gasification Technologies", Bioresource Technology, Volume 83, pp. 55-63, May, 2002.

[18] Goransson, K., Soderlind, U., He, J., and Zhang, W., "Review of Syngas Production via Biomass DFBGs", Renewable and Sustainable Energy Reviews, Volume 15, pp. 482-492, 2011.

[19] Ngo, S.I., Nguyen, T.D., Lim, Y.I., Song, B.H., Lee, U.D., and Choi, Y.T.,"Performance Evaluation for Dual Circulating Fluidized-Bed Steam Gasifier of Biomass Using Quasi-Equilibrium Three-Stage Gasification Model”, Applied Energy, Volume 88, pp. 5208-5220, December, 2011.

[20] Song, T., Wu, J., Shen, L., and Xiao J., "Experimental Investigation on Hydrogen Production from Biomass Gasification in Interconnected Fluidized Beds", Biomass and Bioenergy, Volume 36, pp. 258-267, 2012.

[21] Bain, R., "An Overview of Biomass Gasification", Proceedings of AIChE Spring National Meeting, pp. 375-381, 2004.
[22] Asadullah, M., "Barriers of Commercial Power Generation Using Biomass Gasification Gas: A Review”, Renewable and Sustainable Energy Reviews, Volume 29, pp. 201-215, January, 2014.

[23] Marsh, R., Hewlett, S., Griffiths, T., and Williams, K., "Advanced Thermal Treatment for Solid Waste a Wastemanager's Guide", Proceeding of 22nd International Conference on Solid Waste Management and Technology, Philadelphia, USA, 2007.

[24] Aljbour, S.H., and Kawamoto, K., "Bench-Scale Gasification of Cedar Wood Part-I: Effect of Operational Conditions on Product Gas Characteristics", Chemosphere, Volume 90, pp. 1495-1500, January, 2013.

[25] Aljbour, S.H., and Kawamoto, K., "Bench-Scale Gasification of Cedar Wood Part-II: Effect of Operational Conditions on Contaminant Release", Chemosphere, Volume 90, pp. 1501-1507, January, 2013.

[26] Chen, W., Annamalai, K., Ansley, R.J., and Mirik, M., "Updraft Fixed Bed Gasification of Mesquite and Juniper Wood Samples", Energy, Volume 41, pp. 454-461, May, 2012 .

[27] Calvo, L.F., Gil, M.V., Otero, M., Morán, A., and García, A.I., "Gasification of Rice Straw in a Fluidized-Bed Gasifier for Syngas Application in Close-Coupled BoilerGasifier Systems", Bioresource Technology, Volume 109, pp. 206-214, April, 2012.

[28] Meng, X., Jong, W., Fu, N., and Verkooijen, A.H., "Biomass Gasification in a $100 \mathrm{kWth}$ Steam-Oxygen Blown Circulating Fluidized Bed Gasifier: Effects of Operational Conditions on Product Gas Distribution and Tar Formation”, Biomass and Bioenergy, Volume 35, pp. 2910-2924, July, 2011.

[29] Jordan, C.A., and Akay, G., "Occurrence, Composition and Dew Point of Tars Produced during Gasification of Fuel Cane Bagasse in a Downdraft Gasifier", Biomass and Bioenergy, Volume 42, pp. 51-58, July, 2012.

[30] Sheth, P.N., and Babu, B.V., "Experimental Studies on Producer Gas Generation from Wood Waste in a Downdraft Biomass Gasifier", Bioresource Technology, Volume 100, pp. 3127-3133, July, 2009. 
[31] Jaojaruek, K., Jarungthammachote, S., Gratuito, M.K., Wongsuwan, H., and Homhual, S., "Experimental Study of Wood Downdraft Gasification for an Improved Producer Gas Quality through an Innovative Two-Stage Air and Premixed Air/Gas Supply Approach”, Bioresource Technology, Volume 102, pp. 4834-4840, April, 2011.

[32] Olgun, H., Ozdogan, S., and Yinesor, G., "Results with a Bench Scale Downdraft Biomass Gasifier for Agricultural and Forestry Residues", Biomass and Bioenergy, Volume 35, pp. 572-580, January, 2011.

[33] Wei, L., Xu, S., Zhang, L., Zhang, H., Liu, C., and Zhu, H., "Characteristics of Fast Pyrolysis of Biomass in a Free Fall Reactor", Fuel Processing Technology, Volume 87, pp. 863-871, October, 2006.

[34] Bridgwater, A.V., "The Technical and Economic Feasibility of Biomass Gasification for Power Generation”, Fuel, Volume 74, pp. 631-653, May, 1995.

[35] Ciferno, J.P., and Marano, J.J., "Benchmarking Biomass Gasification Technologies for Fuels, Chemicals and Hydrogen Production", US Department of Energy, National Energy Technology Laboratory, 2002.

[36] Bohlig, J.W., and Casella, D.R., "System and Method for Integrated Waste Storage", Google Patents, 2015.

[37] Basu, P., "Combustion and Gasification in Fluidized Beds", CRC Press, 2006.

[38] Zhou, Z.Q., Ma, L.L., Yin, X.L., Wu, C.Z., Huang, L.C., and Wang, C., "Study on Biomass Circulation and Gasification Performance in a Clapboard-Type Internal Circulating Fluidized Bed Gasifier", Biotechnology Advances, Volume 27, pp. 612-615, September, 2009.

[39] Shen, L., Gao, Y., and Xiao, J., "Simulation of Hydrogen Production from Biomass Gasification in Interconnected Fluidized Beds", Biomass and Bioenergy, Volume 32, pp. 120-127, 2008.
[40] Moilanen, A., Nasrullah, M., and Kurkela, E., "The Effect of Biomass Feedstock Type and Process Parameters on Achieving the Total Carbon Conversion in the Large Scale Fluidized Bed Gasification of Biomass", Environmental Progress \&Sustainable Energy, Volume 28, pp. 355-359, 2009.

[41] Yassin, L., Lettieri, P., Simons S.J., and Germanà, A., "Techno-Economic Performance of Energy-fromWaste Fluidized Bed Combustion and Gasification Processes in the UK Context," Chemical Engineering Journal, Volume 146, pp. 315-327, February, 2009.

[42] Asadullah, M., Miyazawa, T., Ito, S.I., Kunimori, K., Koyama, S., and Tomishige, K., "A Comparison of $\mathrm{Rh} /$ $\mathrm{CeO}_{2} / \mathrm{SiO}_{2}$ Catalysts with Steam Reforming Catalysts, Dolomite and Inert Materials as Bed Materials in Low Throughput Fluidized Bed Gasification Systems", Biomass and Bioenergy, Volume 26, pp. 269-279, March, 2004.

[43] Arvelakis, S., Gehrmann, H., Beckmann, M., and Koukios, E.G., “Agglomeration Problems during Fluidized Bed Gasification of Olive-Oil Residue: Evaluation of Fractionation and Leaching as Pre-Treatments", Fuel, Volume 82, pp. 1261-1270, July, 2003.

[44] Cao, Y., Wang, Y., Riley, J.T., and Pan, W.P., "A Novel Biomass Air Gasification Process for Producing Tar-Free Higher Heating Value Fuel Gas", Fuel Processing Technology, Volume 87, pp. 343-353, April, 2006.

[45] Li, K., Zhang, R., and Bi, J., "Experimental Study on Syngas Production by Co-Gasification of Coal and Biomass in a Fluidized Bed", International Journal of Hydrogen Energy, Volume 35, pp. 2722-2726, April, 2010 .

[46] Vélez, J.F., Chejne, F., Valdés, C.F., Emery, E.J., and Londoño, C.A., "Co-Gasification of Colombian Coal and Biomass in Fluidized Bed: An Experimental Study", Fuel, Volume 88, pp. 424-430, March, 2009. 
[47] Miccio, F., Piriou, B., Ruoppolo, G., and Chirone R., "Biomass Gasification in a Catalytic Fluidized Reactor with Beds of Different Materials", Chemical Engineering Journal, Volume 154, pp. 369-374, November, 2009.

Murakami, T., Xu, G., Suda, T., Matsuzawa, Y., Tani, H., and Fujimori, T., "Some Process Fundamentals of Biomass Gasification in Dual Fluidized Bed”, Fuel, Volume 86, pp. 244-255, January, 2007.

[49] Lapuerta, M., Hernandez, J.J., Pazo, A., and Lopez, J., "Gasification and Co-Gasification of Biomass Wastes: Effect of the Biomass Origin and the Gasifier Operating Conditions", Fuel Processing Technology, Volume 89, pp. 828-837, September, 2008.

[50] Weerachanchai, P., Horio, M., and Tangsathitkulchai, C., "Effects of Gasifying Conditions and Bed Materials on Fluidized Bed Steam Gasification of Wood Biomass", Bioresource Technology, Volume 100, pp. 1419-1427, February, 2009.

[51] Asadullah, M., Miyazawa, T., Ito, S.I., Kunimori, K., Koyama, S., and Tomishige, K., "Gasification of Different Biomasses in a Dual-Bed Gasifier System Combined with Novel Catalysts with High Energy Efficiency", Applied Catalysis A: General, Volume 267, pp. 95-102, July, 2004.

[52] Arvelakis, S., Gehrmann, H., Beckmann, M., and Koukios, E.G., "Preliminary Results on the Ash Behavior of Peach Stones during Fluidized Bed Gasification: Evaluation of Fractionation and Leaching as Pre-Treatments", Biomass and Bioenergy, Volume 28, pp. 331-338, March, 2005.

[53] Lu, Y.J., Jin, H., Guo, L.J., Zhang, X.M., Cao, C.Q., and Guo, X., "Hydrogen Production by Biomass Gasification in Supercritical Water with a Fluidized Bed Reactor", International Journal of Hydrogen Energy, Volume 33, pp. 6066-6075, November, 2008.

[54] Guo, B., Li, D., Cheng, C., Lü, Z.A., and Shen, Y., "Simulation of Biomass Gasification with a Hybrid Neural Network Model", Bioresource Technology, Volume 76, pp. 77-83, January, 2001.
[55] Oesch, P., Leppamaki, E., and Stahlberg, P., "Sampling and Characterization of High-Molecular-Weight Polyaromatic Tar Compounds Formed in the Pressurized Fluidized-Bed Gasification of Biomass", Fuel, Volume 75, pp. 1406-1412, October, 1996.

[56] Zhou, J., Chen, Q., Zhao, H., Cao, X., Mei, Q., and Luo, Z., "Biomass-Oxygen Gasification in a HighTemperature Entrained-Flow Gasifier", Biotechnology Advances, Volume 27, pp. 606-611, September, 2009.

[57] Jin, H., Larson, E.D., and Celik, F.E., "Performance and Cost Analysis of Future, Commercially Mature Gasification Based Electric Power Generation from Switchgrass", Biofuels, Bioproducts and Biorefining, Volume 3, pp. 142-173, 2009.

[58] Radmanesh, R., Chaouki, J., and Guy, C., "Biomass Gasification in a Bubbling Fluidized Bed Reactor: Experiments and Modeling", AIChE Journal, Volume 52, pp. 4258-4272, 2006.

[59] Skoulou, V., Koufodimos, G., Samaras, Z., and Zabaniotou, A., "Low Temperature Gasification of Olive Kernels in a 5-kW Fluidized Bed Reactor for H2-Rich Producer Gas", International Journal of Hydrogen Energy, Volume 33, pp. 6515-6524, November, 2008.

[60] Kumar, A., Eskridge, K., Jones, D.D., and Hanna, M.A., "Steam-Air Fluidized Bed Gasification of Distillers Grains: Effects of Steam to Biomass Ratio, Equivalence Ratio and Gasification Temperature", Bioresource Technology, Volume 100, pp. 2062-2068, March, 2009.

[61] Campoy, M., Barea, A., Vidal, F.B., and Ollero, P., "AirSteam Gasification of Biomass in a Fluidised Bed: Process Optimisation by Enriched Air", Fuel Processing Technology, Volume 90, pp. 677-685, May, 2009.

[62] Puig-Arnavat, M., Bruno, J.C., and Coronas, A., "Review and Analysis of Biomass Gasification Models", Renewable and Sustainable Energy Reviews, Volume, 14, pp. 2841-2851, 2010. 
[63] Umeki, K., Yamamoto, K., Namioka, T., and Yoshikawa, K., "High Temperature Steam-Only Gasification of Woody Biomass", Applied Energy, Volume 87, pp. 791-798, March, 2010.

[64] Devi, L., Ptasinski, K.J., and Janssen, F.G., "A Review of the Primary Measures for tar Elimination in Biomass Gasification Processes", Biomass and Bioenergy, Volume 24, pp. 125-140, February, 2003.

[65] Narvaez, I., Orio, A., Aznar, M.P., and Corella, J., "Biomass Gasification with Air in an Atmospheric Bubbling Fluidized Bed: Effect of Six Operational Variables on the Quality of the Produced Raw Gas", Industrial \& Engineering Chemistry Research, Volume 35, pp. 2110-2120, 1996.
[66] Qin, Y.H., Feng, J., and Li, W.Y., "Formation of Tar and Its Characterization during Air-Steam Gasification of Sawdust in a Fluidized Bed Reactor", Fuel, Volume 89, pp. 1344-1347, July, 2010.

[67] Rapagnà, S,. and Mazziotti, G., "Devolatilization of Wood Particles in a Hot Fluidized Bed: Product Yields and Conversion Rates", Biomass and Bioenergy, Volume 32, pp. 1123-1129, 2008.

[68] IRENA, "Renewable Power Generation Costs in 2012, An Overview in Editors", 2012.

[69] Lazdans, A., Dace, E., and Gusca, J., "Development of the Experimental Scheme for Methanation Process", Energy Procedia, Volume 95, pp. 540-545, January, 2016. 